\title{
Notes on the Feeding Habits of the Caribbean Watersnake, Tretanorhinus variabilis (Dipsadidae)
}

Yaira López-Hurtado ${ }^{1}$, L. Yusnaviel García-Padrón², Adonis González ${ }^{1}$, Luis M. Díaz ${ }^{3}$, and Tomás M. Rodríguez-Cabrera ${ }^{4}$

1'Instituto de Ecología y Sistemática, La Habana 11900, Cuba (yairahurtado17@gmail.com; yailh@ecologia.cu; adonis@ecologia.cu)

${ }^{2}$ Museo de Historia Natural “Tranquilino Sandalio de Noda,” Martí 202, Pinar del Río, Cuba (yusnaviel@gmail.com)

${ }^{3}$ Museo Nacional de Historia Natural de Cuba, La Habana, Cuba (luisfromcuba@gmail.com)

${ }^{4}$ Sociedad Cubana de Zoología, La Habana 12000, Cuba (tomasmichel.rodriguez@gmail.com)

Abstract.-The Caribbean Watersnake, Tretanorhinus variabilis (Dipsadidae) is one of two aquatic West Indian snakes. Despite being a relatively common species in Cuba and the Cayman Islands, its feeding habits have been poorly studied. Herein we report several new instances of predation by this species on fishes, frogs, and a freshwater crab. The latter represents the first record of durophagy in this species and the third snake reported as a crab eater in the West Indies.

$\mathrm{T}$ he Neotropical snake genus Tretanorhinus (Dipsadidae) comprises four aquatic species: The Caribbean Watersnake (T. variabilis Duméril and Bibron 1854) in the West Indies, the Orange-bellied Swampsnake (T. nigroluteus) from southern Mexico to Panama, Mocquard's Swampsnake (T. mocquardi) from Panama to Ecuador, and the Striped Swampsnake (T. taeniatus) from Colombia to Ecuador (Uetz et al. 2020). The Caribbean Watersnake (Fig. 1) is one of two aquatic West Indian snakes; the other is the Salt Marsh Snake, Nerodia clarkii compressicauda (Natricidae) (Neill 1965; Henderson and Crother 1989; Schwartz and Henderson 1991; Henderson and Powell 2009). Of the five currently recognized subspecies of $T$. variabilis, four are from the
Cuban Archipelago and one occurs on Grand Cayman, the Cayman Islands (Schwartz and Henderson 1991; Henderson and Powell 2009; Estrada 2012; Rodríguez et al. 2013; Fig. 2). The Caribbean Watersnake, which occurs only in aquatic ecosystems, exhibits some morphological adaptations to an aquatic lifestyle. These include dorsally positioned eyes and nostrils (Barbour and Ramsden 1919; Buide 1985; Fig. 1A) and dark markings on a dark olive ground color that blend perfectly with the leaf litter and algae-covered rocks on the bottom of ponds and streams (Fig. 1B). Those characteristics, however, might be considered just a first stage toward the development of more complex adaptations to an aquatic lifestyle (see Lillywhite 2014 for a review).
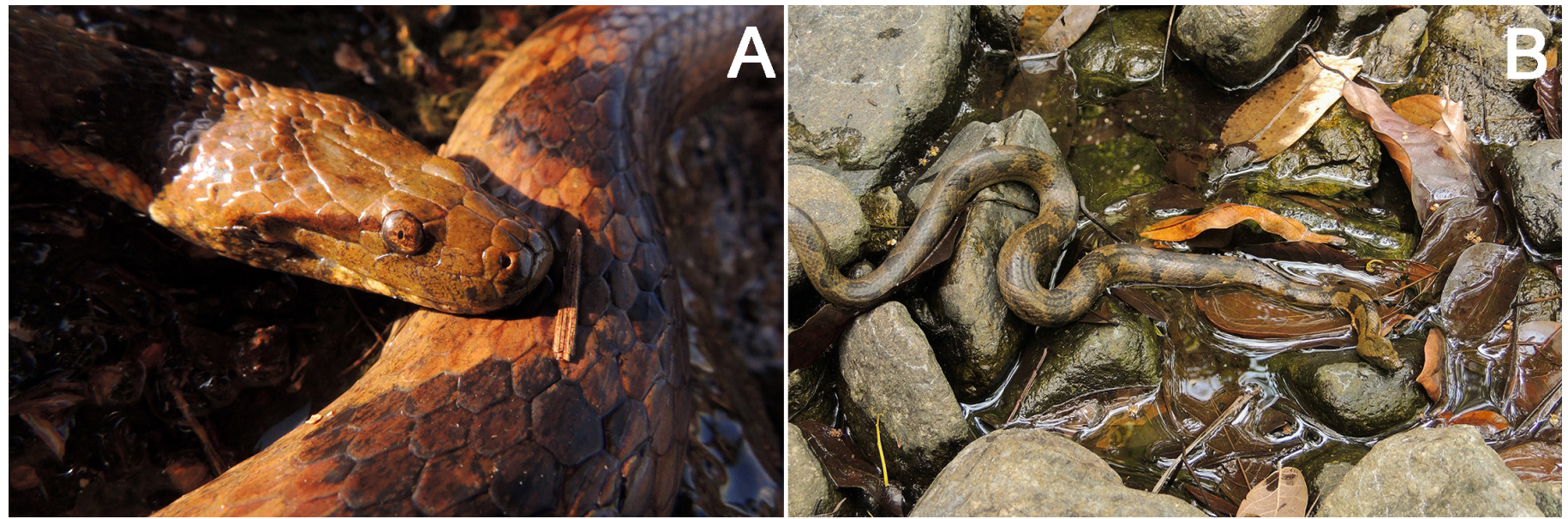

Fig. 1. The Caribbean Watersnake (Tretanorhinus variabilis) exhibits some adaptations to an aquatic lifestyle, such as the eyes and nostrils on top of the head (A) and a color pattern that blends well with the riparian environments it inhabits (B). Photographs (C) T.M. Rodríguez-Cabrera. 
Although this species is relatively common and widely distributed in Cuba (Fig. 2), where it has an elevational range from sea level to 1,000 m (Rodríguez et al. 2010, 2013; Estrada 2012), little is known about its natural history (see Henderson and Powell 2009 for a review). This snake appears to consume mostly fishes, amphibians, and aquatic invertebrates. Barbour and Ramsden (1919) mentioned that it preys on fishes, "usually cyprinodonts, called in Cuba Guajacones" (i.e., Poeciliidae). Neill (1965) found a snake that had consumed a small introduced American Bullfrog (Lithobates catesbeianus) from a river in Pinar del Río Province, which

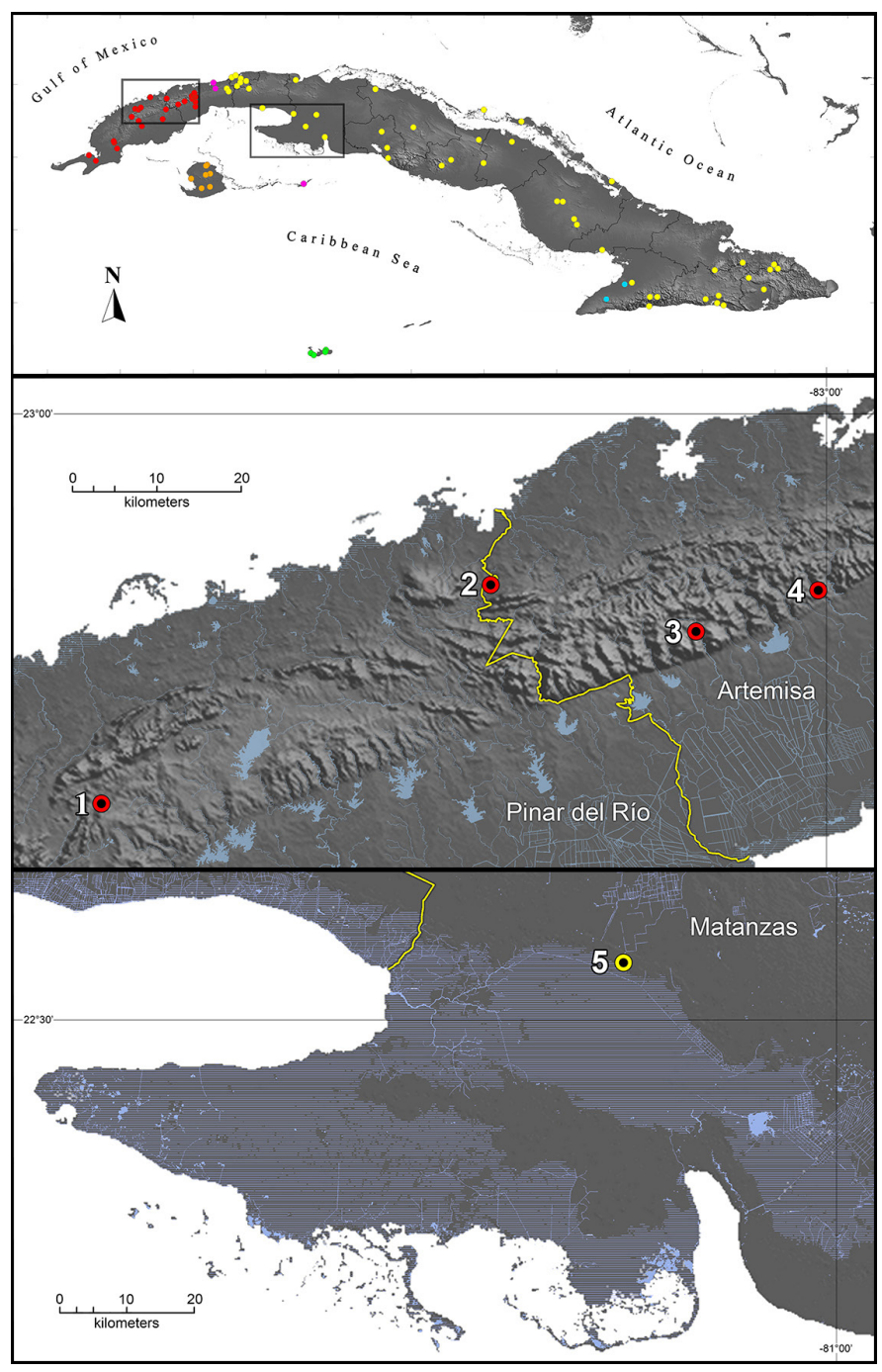

Fig. 2. Distribution of the Caribbean Watersnake (Tretanorhinus variabilis) in Cuba and the Cayman Islands (top): T. v. variabilis (yellow dots), T. v. wagleri (red dots), T. v. insulaepinorum (orange dots), T. v. binghami (blue dots), and T. v. lewisi (green dots); purple dots represent populations not assigned to subspecies (based largely on Schwartz and Henderson 1991; Estrada 2012; Rodríguez et al. 2013; T.M. Rodríguez-Cabrera, per. obs.). A section of western Cuba (center) depicting the locations where we observed predation events and foraging behavior by T. v. wagleri: (1) La Yabita Stream, (2) San Marcos River, (3) Santa Cruz River, and (4) Manantiales River at Soroa. A section of the Zapata Swamp (bottom) showing the location $3 \mathrm{~km}$ south of Peralta (5), were we observed a predation event by $T . v$. variabilis. is the only previously confirmed prey species of this snake. Schwartz and Ogren (1956) mentioned a snake from Granma Province (T. $v$. binghami) that had captured and swallowed a small unidentified fish. Neill (1965) also observed individuals of this species (T. v. binghami) pursuing small fishes by "snapping randomly right and left amidst the darting schools," in the saltwater of a deep ditch in southern Mayabeque Province. Other authors (Vogel 1965; Henderson and Crother 1989; Seidel and Franz 1994; Sampedro and Rodríguez 2003; Díaz and Cádiz 2008) merely listed aquatic invertebrates, fishes, amphibians and their larvae, and small lizards among the prey of this snake, without providing any additional details. Herein we report four instances of predation and one of foraging behavior by Caribbean Watersnakes (T. v. wagleri and T. $v$. variabilis) in western Cuba, including the first case of durophagy in this species.

\section{Methods}

We measured snake snout-vent length (SVL), tail length, and head length to the nearest millimeter using either direct measurements with a measuring tape or a caliper or from photographs using the program ImageJ (v. 1.43; https:// imagej.nih.gov/ij/). In two instances, we estimated total length. We also measured stomach content volumes to the nearest cubic millimeter by noting liquid displacement of distilled water in a graduated cylinder. Data for all coordinates is WGS 84 . Voucher specimens were preserved in ethanol $(75 \%)$ and deposited in the zoological collections of the Museo de Historia Natural "Tranquilino Sandalio de Noda" (MHN.TSN), Pinar del Río, and the Instituto de Ecología y Sistemática (CZACC), La Habana, Cuba.

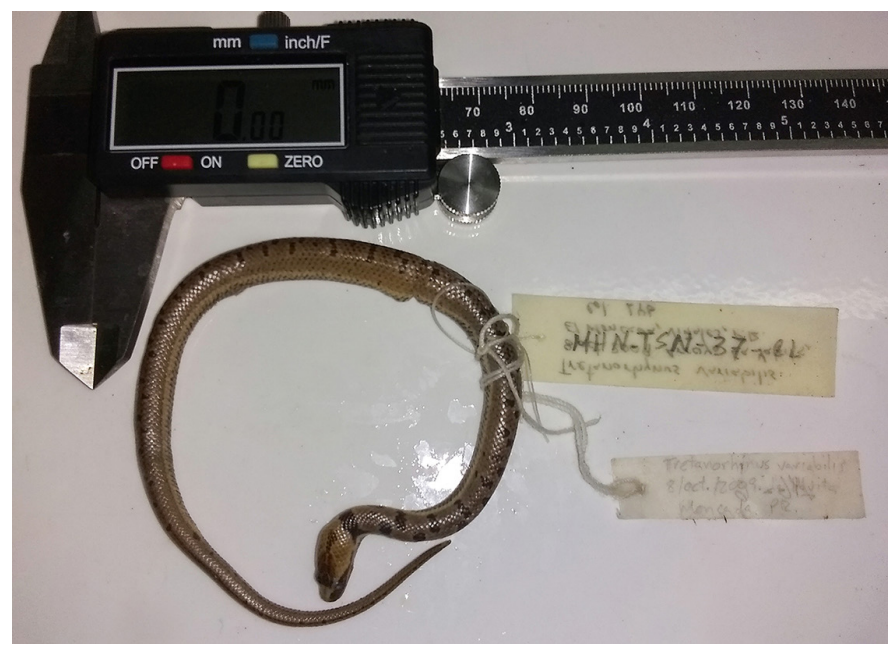

Fig. 3. Juvenile Caribbean Watersnake (Tretanorhinus variabilis, MHN. TSN-37-CL) collected at La Yabita Stream, El Moncada, Viñales Municipality, Pinar del Río Province, containing two partially digested Cuban Streamside Frogs (Eleutherodactylus riparius) in its stomach. Photograph (C) L.Y. García-Padrón. 


\section{Results}

At about $0900 \mathrm{~h}$ on 10 September 2002, we observed an adult female Caribbean Watersnake, T. v. variabilis (ca. 700 $\mathrm{mm}$ total length) with an obvious abdominal bulge in an area of flooded forest known as "Cantabria" in the northernmost portion of the Zapata Swamp, $3 \mathrm{~km}$ south of Peralta, Jagüey Grande Municipality, Matanzas Province $\left(22^{\circ} 35^{\prime} 00^{\prime \prime N}\right.$, $81^{\circ} 18^{\prime} 29^{\prime \prime W}$; ca. $1.5 \mathrm{~m}$ asl; Fig. 2). The snake was initially on land before it responded to our presence by attempting to escape into the water. Forced regurgitation revealed a Biajaca, Nandopsis tetracanthus (Perciformes: Cichlidae) with a total length of about $100 \mathrm{~mm}$.

At 1000 h on 8 October 2009, we collected a juvenile Caribbean Watersnake, T. v. wagleri $(182 \mathrm{~mm} \mathrm{SVL}, 54 \mathrm{~mm}$ tail length, $13 \mathrm{~mm}$ head length) from under a rock in water about $10 \mathrm{~cm}$ deep in La Yabita Stream, El Moncada Town, Viñales Municipality, Pinar del Río Province $\left(22^{\circ} 33^{\prime} 08^{\prime N}\right.$, $83^{\circ} 49^{\prime} 55^{\prime \prime W} ; 150 \mathrm{~m}$ asl; Fig. 2). It contained two partially digested Cuban Streamside Frogs, Eleutherodactylus riparius (Eleutherodactylidae; ca. $17 \mathrm{~mm}$ SVL each; total stomach content volume $690 \mathrm{~mm}^{3}$ ). The snake was preserved and accessioned in the Museo de Historia Natural "Tranquilino Sandalio de Noda," Pinar del Río (MHN.TSN-37-CL; Fig. 3)

At 0900 h on 10 July 2019, we observed an adult male Caribbean Watersnake, T. v. wagleri (ca. $700 \mathrm{~mm}$ total length) foraging in the Manantiales River at Soroa, Candelaria Municipality, Artemisa Province $\left(22^{\circ} 47^{\prime} 38^{\prime \prime N}\right.$, $83^{\circ} 00^{\prime} 30^{\prime \prime} \mathrm{W} ; 150 \mathrm{~m}$ asl; Fig. 2). When first seen the snake

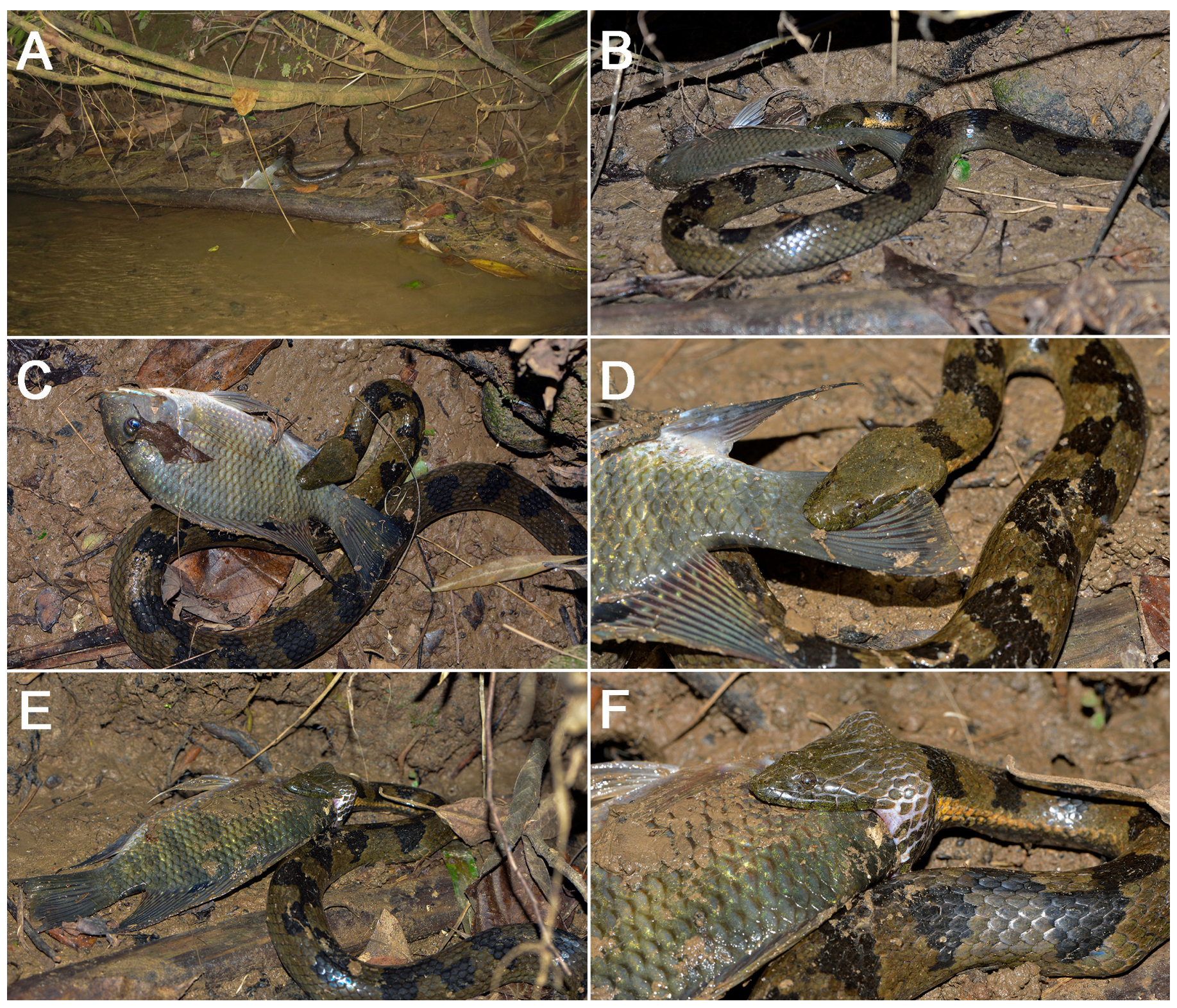

Fig. 4. Sequence of photographs of a predation attempt by a Caribbean Watersnake (Tretanorhinus variabilis) on an introduced Blue Tilapia (Oreochromis aureus) in the San Marcos River: (A) At the moment the snake pulled the fish out of the water; (B-C) holding the fish, notice the disproportionate size of the fish; (D) shifting its hold to the fish's tail, (E) having moved to the head and started swallowing the fish, and (F) the maximum extent of ingestion attained during the attempt to swallow the fish. Photographs (C) A. González (A) and Gustavo Blanco (B-F). 

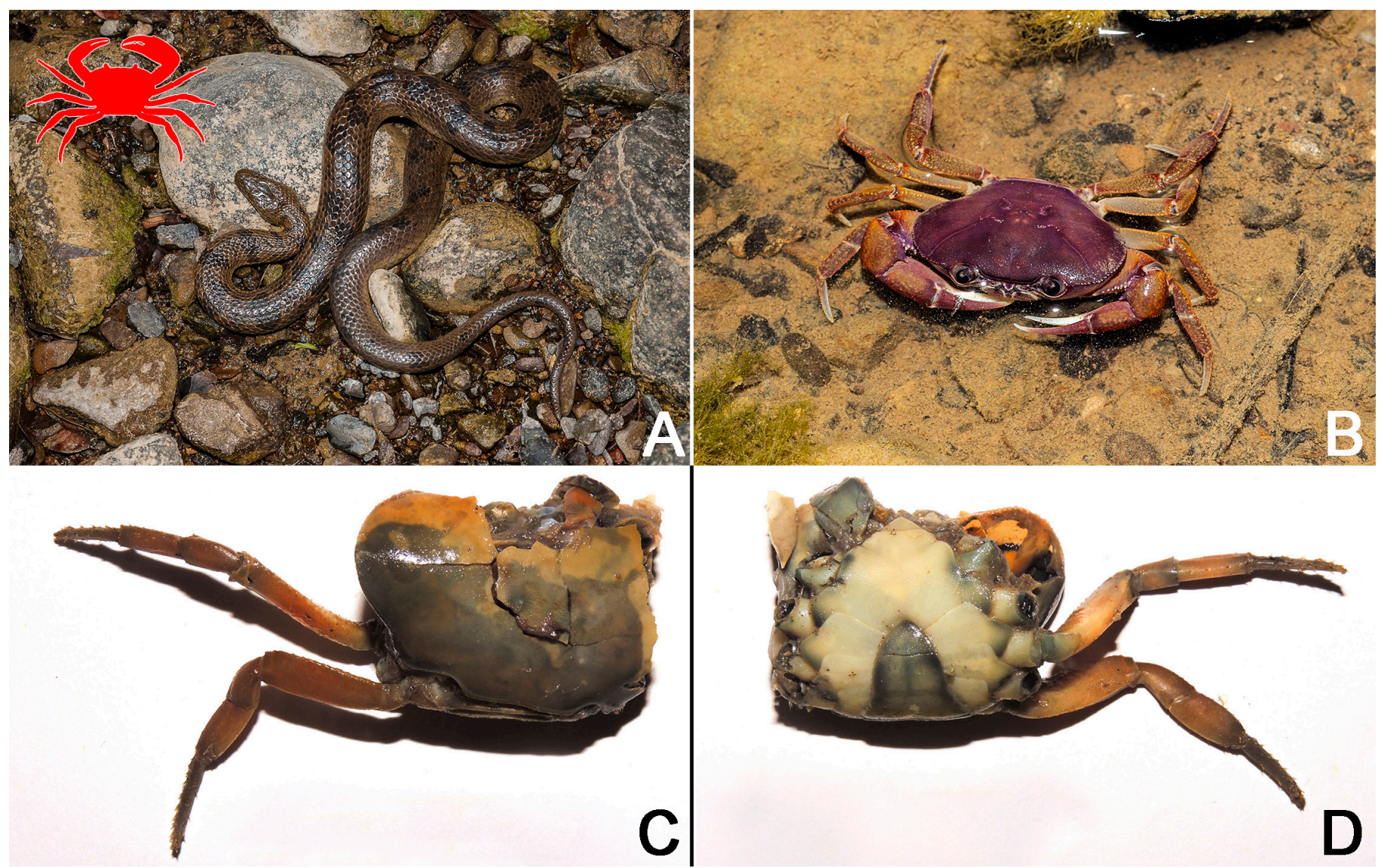

Fig. 5. An adult female Caribbean Watersnake (Tretanorhinus variabilis) (A) in the Santa Cruz River that had ingested a male freshwater crab (Epilobocera gilmani synoecia;); a living adult conspecific freshwater crab from the same locality (B). The crab-shaped inset in " $A$ " represents the proportional size of the prey compared to the snake. Dorsal (C) and ventral (D) views of the ingested crab (CZACC 4.13400). Photographs (C) T.M. Rodríguez-Cabrera (A, B) and Raimundo López-Silvero (C, D).

was coiled on a partially submerged dead branch with the anterior portion of its body in the water apparently trying to capture topminnows (Poeciliidae), which were very abundant close to the bank. Poeciliid species inhabiting that river are Cuban Gambusia (Gambusia punctata), Creole Topminnow (Girardinus creolus), Metallic Girardinus (Gi. metallicus), Singlespot Topminnow (Gi. uninotatus), and Cuban Limia (Limia vittata). Although we did not observe any successful captures, this observation suggests that those fishes likely are components of the snake's diet.

At 0945 h on 29 October 2019, we observed a predation attempt by an unsexed adult Caribbean Watersnake, T. v. wagleri (ca. $750 \mathrm{~mm} \mathrm{SVL}$, tail tip missing, unknown head length; Fig. 4) on a Blue Tilapia, Oreochromis aureus (Perciformes: Cichlidae; ca. $150 \mathrm{~mm}$ total length) in the San Marcos River on the border between La Palma and Bahía Honda Municipalities, Pinar del Río and Artemisa Provinces, respectively (22 $48^{\prime} 14^{\prime \prime} \mathrm{N}, 83^{\circ} 23^{\prime} 06^{\prime \prime} \mathrm{W} ; 30 \mathrm{~m}$ asl; Fig. 2). When we first saw the snake, it was in the water about 2 $\mathrm{m}$ from the opposite riverbank and it had captured the fish by the anal fin region. The snake started to swim in reverse, drawing the fish out of the water (Fig. 4A), remaining in the same position (Figs. 4B-C) for about 17 min until the snake shifted its grip to the fish's tail (Fig. 4D). Some 3 min later, the snake moved its grip to the head of the fish in an attempt to swallow it (Fig. 4E). Ingestion extended to the edge of the operculum (Fig. 4F) but not beyond that point. The snake continued its attempt to swallow the fish for about $1.5 \mathrm{~h}$ before quitting and moving away. At that time, the photographer (G. Blanco) pushed the fish into the water, whereupon it recovered and swam away.

At 2115 h on 13 March 2020, we captured an adult female Caribbean Watersnake, T. v. wagleri $(710 \mathrm{~mm}$ SVL, $150 \mathrm{~mm}$ tail length, $35 \mathrm{~mm}$ head length; Fig. 5A) in the Santa Cruz River, San Cristóbal Municipality, Pinar del Río Province $\left(22^{\circ} 45^{\prime} 00^{\prime \prime} \mathrm{N}, 83^{\circ} 08^{\prime} 58^{\prime \prime W} ; 140\right.$ m asl; Fig. $2)$. Forced regurgitation revealed a partially digested adult male endemic freshwater crab, Epilobocera gilmani synoecia (Pseudothelphusidae; carapace length ca. $22 \mathrm{~mm}$, carapace width ca. $37 \mathrm{~mm}$; total stomach content volume $5,000 \mathrm{~mm}^{3}$ ). We estimated prey size by extrapolating the measurements from other crabs of the same sex and comparable size collected at the same locality (Fig. 5B). The snake was released at the exact site of capture, but the remains of the crab were preserved and accessioned in the Instituto de Ecología y Sistemática, La Habana (CZACC 4.13400). 


\section{Discussion}

The feeding ecology of swampsnakes in the genus Tretanorhinus from continental areas is little studied. Villa (1970) listed fishes (Poeciliidae, Gobiidae, Eleotridae, Pimelodidae, and Rivulidae [as Cyprinodontidae]) and amphibians (Leptodactylidae, Hylidae, Ranidae, and larval toad [Bufonidae]) among the confirmed prey of Orangebellied Swampsnakes in nature. He also listed other fishes and frogs that captive snakes readily accepted. The diets of the other species of Tretanorhinus remain unknown.

The Cuban Streamside Frog (Fig. 6) taken by the Caribbean Watersnake in La Yabita Stream is the first record of a frog in the genus Eleutherodactylus in the diet of a Caribbean Watersnake, which also is the first predator reported for this frog in nature. The Cuban Streamside Frog is a riparian species and is often associated with the same bodies of water as the Caribbean Watersnake (Díaz and Cádiz 2008; Rivalta et al. 2014). The Caribbean Watersnake might be a frequent predator of riparian frogs and other anurans that depend on water to reproduce.

Schwartz and Ogren (1956) mentioned that most of the Caribbean Watersnakes they collected in Granma Province were in quiet areas of streams with their bodies looped around rocks on the bottom close to the banks at night (see also Barbour and Ramsden 1919). In rivers and streams in the Guaniguanico Range in western Cuba and the Guamuhaya Range in central Cuba, we have repeatedly observed this snake patrolling shallow waters $(<30 \mathrm{~cm}$ deep) close to riverbanks at night. In such situations, poeciliids are frequently motionless on the bottom, especially species of Girardinus, as species of Gambusia tend to remain close to the surface even at night (T.M. Rodríguez-Cabrera, pers. obs.). Those observations suggest that the species may be an active forager, although apparently it also uses an ambush strategy (see Results).

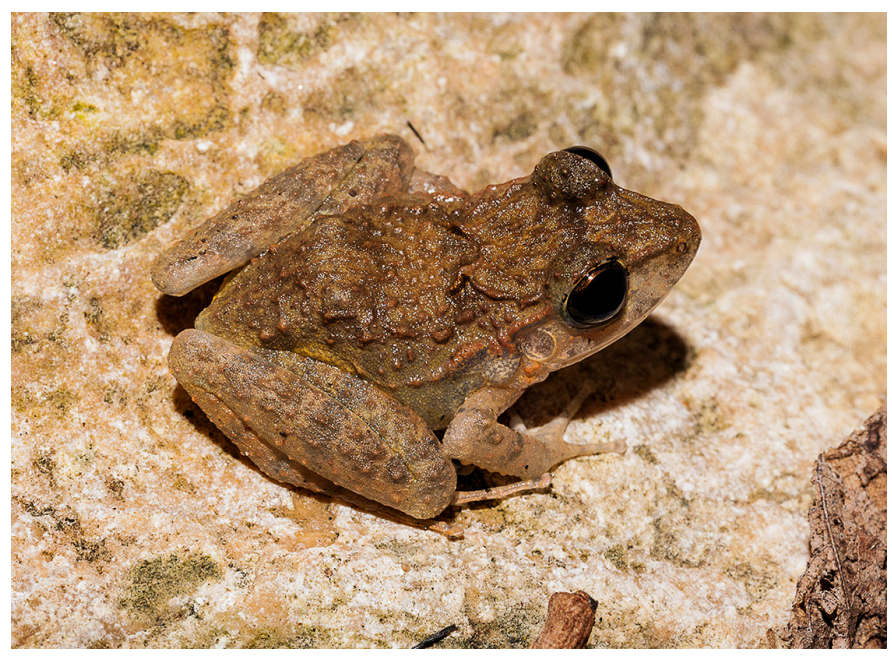

Fig. 6. Adult Cuban Streamside Frog (Eleutherodactylus riparius) from the Sierra del Rosario in western Cuba. Photograph (C) Raimundo López-Silvero.

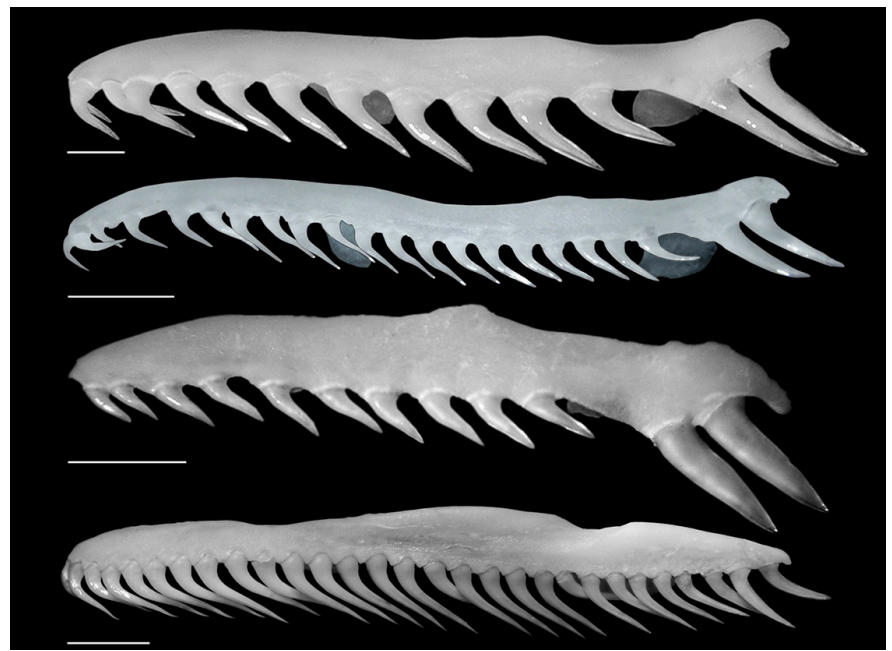

Fig. 7. Comparison of the left maxillae of the four genera of dipsadid snakes present in Cuba. From top to bottom: Cuban Racer (Cubophis cantherigerus), Cuban Lesser Racer (Caraiba andreae), Havana Racerlet (Arrhyton dolichura), and Caribbean Watersnake (Tretanorhinus variabilis). Note the strong opisthoglyphous condition in all genera except Tretanorhinus, which has dentition typical of a piscivorous snake. Scale bars $=1 \mathrm{~mm}$. Photographs (C) T.M. Rodríguez-Cabrera.

Strategies used by aquatic snakes for subduing prey vary from constriction and holding with body loops to envenomation, in addition to other more unusual ways (see Lillywhite 2014 for a review). One of the snakes described herein captured a tilapia at least $2 \mathrm{~m}$ from the bank of a small river before pulling it out of the water. It subsequently remained in the same position, holding the fish for nearly 20 minutes, before initiating attempts to swallow it. Whether gill desiccation is a previously undescribed strategy to subdue relatively large fish is unknown. One alternative explanation for such behavior might be envenomation. Various dipsadids are opisthoglyphous (i.e., with enlarged rear maxillary teeth) and have well developed Duvernoy's glands that produce a toxic saliva (e.g., Myers 1974; Rodríguez-Robles 1992; Rodríguez-Robles and Thomas 1992; Rodríguez-Robles and Leal 1993; Weldon and Mackessy 2010; Rodríguez-Cabrera et al. 2016). However, contrary to many other dipsadids, Caribbean Watersnakes are essentially aglyphous (Fig. 7), equipped instead with a high number of sharp, posteriorly curved teeth, dentition comparable to those of other piscivorous snakes (Savitzky 1983; Knox and Jackson 2010). That, combined with powerful jaw muscles, must provide this snake with a strong bite capable of subduing relatively large prey. Because Tretanorbinus does not represent a basal colubroid clade (Pyron et al. 2011, 2013; Grazziotin et al. 2012), the aglyphous condition would appear to be a derived secondary character. Nonetheless, we cannot rule out envenomation, since studies are necessary to determine whether Caribbean Watersnakes produce a toxic saliva despite its aglyphous dentition. 
The Biajaca is one of two endemic Cuban cichlids (Vergara 1980, 1992b; Froese and Pauly 2019). These medium-sized fish (standard length to $220 \mathrm{~mm}$ ) are abundant and widely distributed in bodies of water all over the main island and Isla de la Juventud (Vergara 1980, 1992b). Only the Cuban Crocodile (Crocodylus rhombifer) and the invasive African Catfish (Clarias gariepinus) were previously reported predators of this species (Ramos et al. 1994, 2010; Hurtado et al. 2016). The Caribbean Watersnake reported herein is the third confirmed predator of this fish, although many aquatic birds prey on fish, including cichlids (e.g., Acosta 1998; Acosta and Mugica 2006; see above), and likely consume Biajacas as well. Another potential predator is the Cuban Gaar (Atractosteus tristoechus), which is known to consume relatively large fish (Vergara 1992a).

Only a handful of snake species in the world are known as crab eaters (e.g., Savitzky 1983; Shine 1985; Green 1997; Jayne et al. 2002, 2018; Murphy and Voris 2002; Voris and Murphy 2002; Lillywhite 2014), probably due to the hard crustacean exoskeleton and powerful claws, which present an effective defense against many predators. One of the Caribbean Watersnakes reported herein is the sixth confirmed predator of pseudothelphusid crabs in the West Indies. Other natural predators that have been reported for crabs in this family include the Cuban Solenodon (Solenodon cubanus), the invasive alien African Catfish, the Yellow-crowned Night-Heron (Nyctanassa violacea), the Red-tailed Hawk (Buteo jamaicensis; see Rodríguez-Cabrera et al. 2018 for a review; but see also Santana and Temple 1988), and the American Bullfrog (García-Padrón et al. in press). The other two snakes reported as crab eaters (not pseudothelphusids) in the region are the Martinique Lancehead, Bothrops lanceolatus (Viperidae; Rufz 1859; De Lalung 1934; B. Raboteau 1968 in Gosner 1987) and the Puerto Rican Boa, Chilabothrus inornatus (Boidae; Wiley 2003). The instance of crab predation described herein represents the first report of durophagy by a Caribbean Watersnake. The Crab-eating Snake (Fordonia leucobalia) and Gerard's Watersnake (Gerarda prevostiana) (Homalopsidae), both from southern Asia, are crab-eating specialists that dismember their prey before ingestion, reducing the impact of constraints imposed by gape size or prey size and morphology (e.g., Jayne et al. 2002, 2018; Murphy and Voris 2002; Voris and Murphy 2002). Although Caribbean Watersnakes are generally considered to be piscivorous and they do not have the adaptations of durophagic snakes (see above; Savitzky 1983), this observation indicates that it is capable of feeding on hard-shelled prey. Since the crab in the stomach of the Caribbean Watersnake was clearly fragmented, we cannot discard the possibility that it used a strategy similar to that of homalopsid snakes, but additional observations are required to corroborate this assumption. In any case, crabs might not be a sufficiently large component of the diet of these snakes to induce morphological adaptations for durophagy.

\section{Acknowledgements}

We thank Raimundo López-Silvero, Rosario Domínguez, Hansel Caballero, Gaciel Artiaga, Gustavo Blanco, and Tomás García and family for assistance in the field, photographs, and/or accommodations. The administration of the National Speleological Training Center "Antonio Núñez Jiménez" provided logistical support and accomodations to the second author. This work was partially funded by the project "Diversidad Biológica Asociada a Ecosistemas Montañosos de las Regiones de Occidente y Centro de Cuba" (Conectando Paisajes), represented by the Ministerio de Ciencia, Tecnología y Medio Ambiente (CITMA) and its Agencia de Medio Ambiente (AMA), and coordinated by the Instituto de Ecología y Sistemática (IES). Finally, Javier Torres made useful comments that improved an earlier version of this manuscript.

\section{Literature Cited}

Acosta, M. 1998. Segregación del nicho en la comunidad de aves acuáticas del agroecosistema arrocero de Cuba. Unpublished Ph.D. Thesis, Facultad de Biología, Universidad de La Habana, La Habana, Cuba.

Acosta, M. and L. Mugica. 2006. Aves en el ecosistema arrocero, pp. 108-135. In: L. Mugica, D. Denis, M. Acosta, A. Jiménez, and A. Rodríguez (eds.), Aves Acuáticas en los Humedales de Cuba. Editorial Científico-Técnica, La Habana, Cuba.

Barbour, T. and C.T. Ramsden. 1919. The herpetology of Cuba. Memoirs of the Museum of Comparative Zoölogy 47: 71-213.

Buide, M. 1985. Reptiles de Cuba. Editorial Gente Nueva, La Habana, Cuba.

De Lalung, H. 1934. Le Serpent de la Martinique. Sa Légende, ses Mœurs, ses Ennemis. Comment les Caraïbes et les Nègres Soignaient ses Piqûres. Essai de Médecine Rétrospective. Laboratoires Corbière, Paris.

Díaz, L.M. and A. Cádiz. 2008. Guía taxonómica de los anfibios de Cuba. Abc Taxa 4: 1-294 (+ CD).

Estrada, A.R. 2012. The Cuban Archipelago, pp. 113-125. In: R. Powell and R.W. Henderson (eds.), Island lists of West Indian amphibians and reptiles. Bulletin of the Florida Museum of Natural History 51: 85-166.

Froese, R. and D. Pauly (eds.). 2019. FishBase. <http://www.fishbase.org>.

García-Padrón, L.Y., J.C. Cordero Acosta, and R. Baños Utria. In press. Is the American Bullfrog competing for food with the Western Giant Toad? Acta Científica.

Gosner, K.L. 1987. Observations on Lesser Antillean pit vipers. Journal of Herpetology 21: 78-80.

Grazziotin, F.G., H. Zaher, R.W. Murphy, G. Scrocchi, M.A. Benavides, Y.-P. Zhang, and S.L. Bonatto. 2012. Molecular phylogeny of the New World Dipsadidae (Serpentes: Colubroidea): a reappraisal. Cladistics 1: 1-23.

Green, H.W. 1997. Snakes: The Evolution of Mystery in Nature. University of California Press, Berkeley, California.

Henderson, R.W. and B.I. Crother. 1989. Biogeographic patterns of predation in West Indian colubrid snakes, pp. 479-518. In: C.A. Woods (ed.), Biogeography of the West Indies. Past, Present, and Future. Sandhill Crane Press, Gainesville, Florida.

Henderson, R.W. and R. Powell. 2009. Natural History of West Indian Amphibians and Reptiles. University Press of Florida, Gainesville, Florida.

Hurtado Consuegra, A., Y. González Delgado, J. González Méndez, R. Santana Aguilar, R. Ramos Targarona, J.L. Jiménez Hernández, O. Senarega Sardiñas, J.C. Cedeño, and S. Kubota. 2016. Biología, Ecología y Aprovechamiento de la Especie Clarias gariepinus, en la Reserva de la Biosfera Ciénaga de Zapata. Centro Nacional de Áreas Protegidas (CNAP), La Habana, Cuba.

Jayne, B.C., H.K. Voris, and P.K.L. Ng. 2002. Snake circumvents constraints on prey size. Nature 418: 143.

Jayne, B.C., H.K. Voris, and P.K.L. Ng. 2018. How big is too big? Using crustacean-eating snakes (Homalopsidae) to test how anatomy and behavior affect prey size and feeding performance. Biological Journal of the Linnean Society 20: 1-15. 
Knox, A. and K. Jackson. 2010. Ecological and phylogenetic influences on maxillary dentition in snakes. Phyllomedusa 9: 121-131.

Lillywhite, H.B. 2014. How Snakes Work. Structure, Function and Behavior of the World's Snakes. Oxford University Press, New York, New York.

Murphy, J.C. and H.K. Voris. 2002. Aquatic snakes with crustacean-eating habits elude herpetologists for two centuries. Litteratura Serpentium 22: 107-114.

Myers, C.W. 1974. Systematics of Rhadinaea (Colubridae), a genus of New World snakes. Bulletin of the American Museum of Natural History 153: 1-262.

Neill, W.T. 1965. Notes on aquatic snakes, Natrix and Tretanorhinus, in Cuba. Herpetologica 21: 62-67.

Pyron, R.A., F.T. Burbrink, G.R. Colli, A. Nieto Montes de Oca, L.J. Vitt, C.A. Kuczynski, and J.J. Wiens. 2011. The phylogeny of advanced snakes (Colubroidea), with discovery of a new subfamily and comparison of support methods for likelihood trees. Molecular Phylogenetics and Evolution 58: 329-342.

Pyron, R.A., F.T. Burbrink, and J.J. Wiens. 2013. A phylogeny and revised classification of Squamata, including 4161 species of lizards and snakes. BMC Evolutionary Biology 13: 93.

Ramos [Targarona], R., V. de Buffrenil, and J.P. Ross. 1994. Current status of the Cuban Crocodile, C. rhombifer, in the wild, pp. 113-140. In: Crocodiles. Proceedings of the 12th Working Meeting of the Crocodile Specialist Group of the Species Survival Commission of IUCN-The World Conservation Union convened at Pattaya, Thailand, 2-6 May 1994. IUCN, Gland, Switzerland.

Ramos Targarona, R., R. Rodríguez Soberón, M. Alonso Tabet, and J. Thorbjarnarson. 2010. Cuban Crocodile Crocodylus rhombifer, pp. 114-118. In: S.C. Manolis and C. Stevenson (eds.), Crocodiles. Status, Survey and Conservation Action Plan. Third Edition. Crocodile Specialist Group, Darwin, Australia.

Rivalta González, V., L. Rodríguez Schettino, C.A. Mancina, and M. Iturriaga. 2014. Amphibians of Cuba: Checklist and geographic distributions. Smithsonian Herpetological Information Service 145: 1-48.

Rodríguez-Cabrera, T.M., J. Torres López, R. Marrero, and J.A. Podio Martínez. 2016. Predation attempt by the Cuban Racer, Cubophis cantherigerus (Squamata: Dipsadidae) on the Cuban Giant Anole, Anolis equestris buidei (Squamata: Dactyloidae), a threatened endemic subspecies. Reptiles \& Amphibians 23: 46-50.

Rodríguez-Cabrera, T.M., A. del Río Leal, and S. Rodríguez-Machado. 2018. First record of predation on the Cuban endemic freshwater crab Epilobocera capolongoi (Brachyura: Pseudothelphusidae). Poeyana 507: 84-86.

Rodríguez-Robles, J.A. 1992. Notes on the feeding behavior of the Puerto Rican Racer, Alsophis portoricensis (Serpentes: Colubridae). Journal of Herpetology 26: $100-102$.

Rodríguez-Robles, J.A. and M. Leal. 1993. Effects of prey type on the feeding behavior of Alsophis portoricensis (Serpentes: Colubridae). Journal of Herpetology 27: 163-168.

Rodríguez-Robles, J.A. and R. Thomas. 1992. Venom function in the Puerto Rican Racer, Alsophis portoricensis (Serpentes: Colubridae). Copeia 1992: 62-68.

Rodríguez Schettino, L., V. Rivalta González, and E. Pérez Rodríguez. 2010.
Distribución regional y altitudinal de los reptiles de Cuba. Poeyana 498: 11-20.

Rodríguez Schettino, L., C.A. Mancina, and V. Rivalta González. 2013. Reptiles of Cuba: Checklist and geographic distribution. Smithsonian Herpetological Information Service 144: 1-96.

Rufz, E. 1859. Enquête suer le Serpent de la Martinique. Chez Germer Bailliere, Paris, France.

Sampedro Marín, A. and L. Rodríguez Schettino. 2003. Reptiles acuáticos, pp. 128-137. In: L. Rodríguez Schettino (ed.), Anfibios y Reptiles de Cuba. UPC Print, Vaasa, Finland.

Santana, E.C. and S.A. Temple. 1988. Breeding biology and diet of Red-tailed Hawks in Puerto Rico. Biotropica 20: 151-160.

Savitzky, A.H. 1983. Coadapted character complexes among snakes: Fossoriality, piscivory, and durophagy. American Zoologist 23: 397-409.

Schwartz, A. and R.W. Henderson. 1991. Amphibians and Reptiles of the West Indies. Descriptions, Distributions, and Natural History. University of Florida Press, Gainesville, Florida.

Schwartz, A. and L.H. Ogren. 1956. A collection of reptiles and amphibians from Cuba, with the description of two new forms. Herpetologica 12: 91-110.

Seidel, M.E. and R. Franz. 1994. Amphibians and reptiles (exclusive of marine turtles) of the Cayman Islands, pp. 407-433. In: M.A. Brunt and J.E. Davies (eds.), The Cayman Islands: Natural History and Biogeography. Kluwer Academic Publishers, Dordrecht, The Netherlands.

Shine, R. 1985. Prey constriction by venomous snakes: a review, and new data on Australian species. Copeia 1985: 1067-1071.

Uetz, P., P. Freed, and J. Hošek (eds.). 2020. The Reptile Database. <http://www. reptile-database.org>.

Vergara R., R. 1980. Principales características de la ictiofauna dulceacuícola cubana. Ciencias Biológicas 5: 95-106.

Vergara R., R. 1992a. Desarrollo Evolutivo de la Ictiofauna Dulceacuícola Cubana con Especial Referencia a los Ciprinodontiformes. Primera edición. Vol. 1. Editorial Academia, La Habana, Cuba.

Vergara R., R. 1992b. Principales Características de la Ictiofauna Dulceacuicola Cubana. Información Adicional I. Editorial Academia, La Habana, Cuba.

Villa, J. 1970. Notas sobre la historia natural de la serpiente de los pantanos, Tetanorhinus nigroluteus. Revista de Biología Tropical 17: 97-104.

Vogel, Z. 1965. Herpetologische Beobachtungen auf Kuba (III). Aquarium Terrarium 12: 340-343 (reprinted in Dutch as Herpetologische waarnemingen op Cuba IV. Lacerta 24: 75-77).

Voris, H.K. and J.C. Murphy. 2002. The prey and predators of homalopsine snakes. Journal of Natural History 36: 1621-1632.

Weldon, C.L. and S.P. Mackessy. 2010. Biological and proteomic analysis of venom from the Puerto Rican Racer (Alsophis portoricensis: Dipsadidae). Toxicon 55: 558-569.

Wiley, J.W. 2003. Habitat association, size, stomach contents and reproductive conditions of Puerto Rican Boas (Epicrates inornatus). Caribbean Journal of Science 39: 189-194. 